\title{
Mobile Assisted Language Learning in Intensive English Course for Freshmen Year Students
}

\author{
Made Agus Mandala Putra \\ English Language Education/Faculty of Language and Art Ganesha University of Education, Singarja Indonesia \\ Email: mamandalaputra@gmail.com \\ Made Hery Santosa \\ English Language Education/ Faculty of Language and Art Ganesha University of Education, Singarja Indonesia \\ Email: mhsantosa@undiksha.ac.id
}

\author{
A R T I C L E I N F O \\ Article history: \\ 1 Maret 2020 Received in \\ revised form \\ 30 Maret 2020 \\ Accepted 11 April 2020 \\ Available online 15 \\ Mei 2020

Kata Kunci:
$I E C, \quad M A L L, \quad$ Mahasiswa
tingkat pertama \\ Keywords: \\ IEC, MALL, first semester \\ students
}

\begin{abstract}
A B S T R A K
Pembelajaran abad ke 21 telah mempengaruhi penggunaan teknologi dalam pembelajaran di kelas. Selebihnya, Mahasiswa generasi digital telah mengetahui peran dari terknologi dan telah berhasil beradaptasi didalamnya. Oleh karena itu sangat penting untuk memperkenalkan pembelajaran yang atraktif dan aktif dengan menggunakan kegiatan autentik dan salah satu kegiatan tersebut bernama Mobile Assisted Language Learning (MALL). Pembelajaran ini membawa informasi dunia hanya kedalam perangkat telepon pintar mahasiswa. Sebaliknya dalam pembelajaran tradisional di dalam kelas, mahasiswa tidak sepenuhnya menimba ilmu di dalam kelas. Faktanya, dengan melaksanakan pembelajaran melalui $M A L L$ dapat memberi kebebasan mahaiswa untuk belajar dalam segi waktu dan tempat. Hasil penelitian memaparkan bahwa mahasiswa mengalamai kendala dlam pembelajaran terutama dalam beraktivitas dan penggunaan media ajar. Mahasiswa membutuhkan media pembelajaran yang autentik yang dapat meningkatkan 4 skill bahasa Inggris mereka.
\end{abstract}

\begin{abstract}
A B S T R A C T
Learning on twenty first century has influenced the use of technology especially as contextual learning media in the classroom. Moreover, digital generation students have already known the role of technology and have adapted it successfully. Therefore, it was very important to introduce attractive and active learning by using authentic activities and one of these activities was called Mobile Assisted Language Learning (MALL). This learning brought the world's information only to the students' smart phone. In contrast to traditional learning in the classroom, the students did not fully gain knowledge in the classroom. In fact, the implementation of MALL could give students' freedom to learn in terms of time and place. The result of this research showed that students had obstacles in learning especially in terms of activities and the used of teaching media. Students needed authentic learning media that could improve their four skills.
\end{abstract}

\section{Introduction}

Technology has affected the human activities become easier to be conducted. Since the $21^{\text {st }}$ century established it is found that the technology has taken many important roles in human life. The twenty-first century has affected many aspects of activities including in learning activity in the classroom, whether it is affected by the students or teacher itself (Sasmoko, 2017). It means that technology is used as information resources by students in learning. Furtherance, it has influenced the 21 th century of learning. This learning can be categorized as digital learning classroom. Related to the character of $21^{\text {th }}$ students, the use of technology cannot be separated on students' life, students have good ability in possessing the ICT(Kopáčková, 2016). On the other hand, ICT has become the media used by the students and teacher to face in teaching and learning classroom. Teacher and students should be able to master the technology itself, as the importance of the development of technology that will lead the students to face the $21^{\text {st }}$ century skill which is about digital literacy (Yaman, Senel, \& Yasilel, 2015).

Digital literacy which being apart in $21^{\text {st }}$ century skills is one of important skill that should be taught in the classroom by the teacher in order to build efficient in using the digital technology, communication devices, and the network in digital environments to live life efficiently (Phuapan, Viriyavejakul, \& Pimdee, 2015). Moreover, Glister (1997) utters that digital literacy is ability in understanding information in every different format of sources. It means that the teacher responsibility to help the students to manage the skill to promote students engagement in learning through technology. One of potential learning activities conducted in today's learning combined with technology is called mobile learning (M-learning). It is providing information about educational content in small pocket device (Ligi, 2017). While Quinn (2000) proposes that m-learning is conducting learning activity by using mobile phone. By learning using technology students will have no 
limitation in time and space. It means students will have freedom to decide their learning activities. Different in learning language with mobile phone, Mobile Assisted Language Learning is another mobile phone-based learning activity.

Mobile Assisted Language Learning (MALL) is the use of mobile phone in learning target language (Miangah \& Nezarat, 2012). The role of technology especially in teaching language has been elaborated by using mobile phone. Since then, students have integrated their learning activities both in and outside of the classroom by using mobile phone. On the other hand, a previous study conducted by Mandala Putra, Santosa, \& Susanti, (2018) have found that the use of smartphone-based application has significant effect in improving students' speaking competency. Furthermore, learning language by MALL can enhance students' English ability. Furthest, the core of applying MALL is to build autonomous learning ability for the students. This new model of learning activities has successfully minimized the time and space consuming; learning through students' mobile phone is easier to be implemented (Sato, Murase, \& Burden, (2015) especially in learning target language (English).

Bali especially has become one of the first tourism destination in this world have to prepare the world diversity especially in using English as the communication medium, another thing is the era of Economic Asean Community (AEC) has been established in Indonesia which means the future career has widely opened. The role of English language has taken important point on this era. It is followed with the development of technology which has proceeded in tandem. The rapid development of technology has been not followed with the ability of mastering the English language itself. According to English Proficiency Index, Indonesia students generally have lowest English proficiency. It means, students have small chance to compete in this era. Being able to master English is not just about understand to communicate only, but managing others English skills are important to be mastered.

Four English language skills are four basic skills in English that should be managed by the students in order to be a good English user. Moreover, Lorena \& Sadiku (2015) addresses that four English skills are the integration of speaking, listening, writing, and reading. Thus, those skills are related to each other. In this case, students are having a course which has integrated those English skills. The name of the course is Intensive English Course (IEC). Teaching in conventional way is not appropriate anymore to be used in teaching generation z (Fatimah, 2017), the deal of students today is engaging with their smartphone. One today's students characteristic is conducting their activities including learning activities through their smarphone (Csobanka, 2016). Moreover, adapting technology by students has fully discovered which make them able to master the technology itself.

The researcher has conducted preliminary observation to find out the real phenomenon happened in the classroom in learning Intensive English Course. It showed that students have limited information of English Language to be used to conduct both produce and receive English skill. Furthermore, the tent of students being active in the classroom was bigger. It sign that students did not have any good foundation in English in order to be used to communicate, give opinion, or ask to their teacher. Lecturers also still tent to use paper-based textbook in lecturing the students, which that traditional activity does not help the students anymore. If it is repeatedly continued, it will affect students' performance in English. The role of technology is important to be used by the students (Hashim, 2018).

Previous study has been conducted by (Darmuki, Andayani, Nurkamto, \& Saddhono, 2016) entitled Need Analysis Model Student Learning to Speak for Education Study Language and Literature Indonesia. The study has found four main problems and needs for students in language learning. The major problem is students need motivation in learning speaking for higher education. It is because students feel inadequate on their English ability. Second one is students' interesting in learning how to speak properly. The third one is experience appreciation speaking in university receptively. Last one is the experience of appreciation speaking in university productively. Further, a research by Ulum (2016) entitled A Needs Analysis Study for Preparatory Class ELT Students. The study has found that students need authentic materials to be implemented in speaking learning. Based on these two previous studies, it found that students need highly motivated, authentic and interesting activities should be put into practice to maintain the success of the course. Thus, $21^{\text {st }}$ students' needs proper learning media which it is wrapped with authentic and motivate students learning and it can be integrated using technology as the learning media to be used to engage their target language language.

In summary, this study aims to identify the students and lecturers' need toward the use of technology especially the use of mobile phone in language teaching and learning. Since the role of technology has affected the learning process, it means that students have fluency in adapting technology on them. Nevertheless, students' proficiency was not improved as the development of the technology. Hence, in order to increase students four English learning skills, identify the need of students is important to be conducted to make right and meaningful decision in later implementing mobile assisted language learning in the classroom. Interview guide for students and lecturers will be provided to get access data for this research and the result will be described qualitatively. A previous study has been conducted by Bezircilioğlu (2016) who compose that learning by media device is 
needed by the students to improve students language knowledge and it has given the students role in language learning and it will lead the access of wide knowledge.

\section{Method}

Qualitative research was conducted which were then six freshmen year students of English language education in Ganesha University and five lecturers were interviewed to identify the deep information of students need in learning language using mobile phone. Interview is used when the researcher wants to know about the deep information from the respondent (Sugiono, 2010). Students and lecturers were selected from different classes and based on their IEC book taught in the classroom. Moreover, nine items of questions have been prepared to be asked to the students and twelve items of questions were prepared to be asked to the lecturers. Both students and lecturers' questions have been designed the blue print which adapted from Bonces, (2012), Zhang \& Burston (2011), Madhumathi (2017), and Klopfer, Squire, and Jenkins, (2002). The result of the interview vividly described.

\section{Lecturer interview result}

\section{Results and Discussion}

There were twelve questions asked to the lecturers and the results are: the first, the researcher asked about the use of media in teaching activities in the classroom. The answers were all of the lecturers already have used media for teching in the classroom. In this point lecturers were had several media used especially which engaged with technology. The second one, the researcher asked about the types media used by the lecturers in their classroom during the classroom activities. From those five lecturers, it was found only two lecturers who were already implemented smartphone-based application media they were padlet and kahoot in teaching learning activities along with power point and textbook, while another lecturer has still implemented textbook-based activities. The third one, the researcher asked about the frequencies of the media used during the learning time. The result showed that the media used by the lecturers were depended on the material given. For the use of smartphone-based application only a quarter of 16 meetings conducted. The fourth one, the researcher asked to the lecturers about the response of their students during the use of their media in the classroom. They mostly answered that their students enjoyed with the media used by the lecturers. However, it still made them passive in learning especially due to conventional media used by their lecturer.

The fifth one, the researchers asked about the use of smartphone-based application in teaching activities. The lecturers answered that only two of them already used smartphone-application while the rest have thought whether to use it or not, but they could not find any appropriate application to be used in helping them in teaching their materials. The sixth one, the researcher asked the interviewees about their understanding in integrated learning. The answers were mostly the same they were concluded that integrated learning is how the learning activities are integrated with various learning media especially by the technology and strategies that will help to cover the four of English skills which those four skills are needed by the students to develop their English. The seventh one, the researcher asked about the importance of language and content in integrated material. The lecturers cohesively answered that both between content and language are important in supporting the integrated material, both of them are connected to each other. The lecturers also agreed that both between language and content cannot be separated. The eighth one, the researcher asked to the lecturer about the strength of the implementation smartphone-based application in learning activities. The strengths are by using technology especially smartphone media in teaching, it can make faster for the lecturers in delivering the materials, and easier for the students learn with different several of resources in learning. Another one is, by implementing technology in learning will help students to face the industry 4.0 and AEC. The ninth one, the researcher asked to the lecturer about the weakness of the implementation smartphone-based application in learning activities. the weaknesses are only on with its outside factor, they are: signal, quota for them who are not using wifi signal, and students still tend to switch their screen to other things like social media, and the type of smartphone itself, sometimes they are still use low quality of smartphone. The tenth one, the researcher asked if there is an innovative learning media through smartphone-media based, will the lecturers support the media to be used as the learning media in teaching English. The feedbacks were good, all of the interviewees were interested in using the product. They said will support if the media which can be accessed everywhere and anytime and offer attractive learning process. And also as long it is supported with the learning materials taught by them.

The eleventh one, the researcher asked about proper topic which is the integrated one that should be implemented in the application product. The lecturers gave the researcher one topic in every IEC book. For the IEC book 1A the lecturer suggested to develop a material with topic meeting at the campus, the second lecturer who handled IEC book 2A suggested implementing a topic about school uniform, the third lecturer who handled IEC book 3A directions, for book IEC 1B suggested to promote a topic about weather, and the last lecturer from book IEC 2B has suggested to use a topic about obligation and necessity. The twelfth one, the researcher asked about the proper questions need to be given and designed for students in one topic. The lecturers answered that 
the number of proper questions for students are depends on the material but commonly for the level of first semester students the lecturers decided to give 10 to 20 questions within different authentic assessments, because university students need challenge which can stimulate their brain to solve the problem independently.

In conclusion, the lecturers have implemented some various media in learning activities, but there were only two lecturers who had used smartphone-based application in teaching while the rest still frequently used power point and textbook. The lecturers were already known well and aware of the 21th century of learning which the screenagers will more engage with technology in learning and they understand well with integrated learning and its importance between language and content, but some technical issues such as connection, smartphone brand, and quota can be one of problems facing by the students. Moreover, the lecturers have divided to five topics which should be developed in the application product complete with its number of task or proper questions to be used in the smartphone-based learning media.

\section{Students interview result}

There were nine questions asked to the seven freshmen year students and the results are, the first one, the researcher asked about the students' feeling during the IEC learning activities. Students were quite enjoy with the learning activities given by their lecturers, despite of the materials were easy the lecturers offered fun attractive learning activities, but some of the respondents did not feel the same because some lecturers had minimum experience in teaching on this course since they are new comers, furthermore students also felt bored because the course been divided into several parts. Students thought that it has consumed much time in learning and not all the important materials were completely given due to limit of time. Another one, the lecturer still fully taught using textbook which made them have less sources of information.

The second one, the researcher asked about the implementation of technology in learning, especially the use of smartphone-based application by their lecturers in the classroom. Students responded that only two lecturers are using smartphone application (Kahoot and Padlet) in their learning activities, the rest are still using other technologies such as power point, and paper-based such as flash card and scramble sentences. There were only 2 smartphone applications only used to assess. Kahoot is used for giving quizzes and padlet for giving material such as video which only used to develop students vocabulary only. The third one, the researcher asked about the students' familiarity in using smartphone application in doing their daily activities. Based on the answers, students are familiar with the use of smartphone application to support their daily life, especially to communicate and get some information and news. The fourth one, the researcher asked about students' activities by using their smartphone. The response indicated that the students already used their smartphone for studying in term of translating words and improving certain skill not for increasing four English skills yet, browse any information but also some of them use it to communicate with others and playing games or seeking for others entertainments like watching Youtube or listening to music. The fifth one, the researcher asked students' frequent of time in using their smartphone. The time consumptions were different from every student. The first student spent 9 hours a day, second students spent 14 hours a day, third student spent 6 to 8 hours a day, and fourth student spent 5 hours a day, fifth student spent 10 to 12 hours a day, sixth student spent 9 hours a day, and for the seventh student spent 8 to 10 hours a day. Averagely the students spent 9.5 hours a day to play with their smartphone, whether for communication, game, study, or doing other entertainments.

The sixth one, the researcher asked students about the applications have been installed in their smartphone. The result is six of seven students already installed some application like dictionary, Google translate, Kahoot, and Yuotube. 1 student installed speaking application namely Elsa speak, 1 installed their phone with IELTS listening application and Schoology, and 1 student have not installed any application. Based on the result, students only installed applications which only focus to help them at least to learn 2 English skill and competence. The seventh one, the researcher asked about the function of their learning applications increase for. For dictionary, Google translate, youtube, kahoot were used by students to enrich their vocabulary, while Elsa speak was used by students to increase their speaking skill, IELTS listening was used by the students to develop listening ability to face IELTS test and Schoology literally used for receiving information posted by the lecturer in online lecturing section.

The eighth one, the researcher asked students' expectation about learning English through their smartphone-based application. From the students response it can be summarized that Students are expected that they could interact more in learning with their smartphone, challenging game which can motivate them to learn, fast and efficiency, help them to listen the native speaker itself and to improve their listening and pronunciation. Also an application which capable to teach grammar and has many features to make students more engage in learning. The application provides material and quizzes which can increase and enrich students' engagement in English, moreover the application which capable to teach or cover English four skills. The ninth one, the researcher asked students' interest to support and use the new application made by the researcher. And the response was open minded, the students were really want to try the application which can make them learn English more everywhere and anywhere just only with their smartphone. 
In coclusion, students are need a new attractive, fun, challenging, and complex learning media smartphone-based application which can covers those 4 English skills and competencies which wrapped with materials and quizzes. Students have many hours in using their phone, but it is not supported with the applications used on their daily study. It means that they are lack of media to be used in learning English especially to cover four English skills and competencies. Another thing, the application also should be able to motivate and provide with another challenging learning game-based.

\section{Discussion}

Based on the need analysis conducted from the interview, fresh graduate students of English Language Education have already used smartphone in their daily life activities including helping to solve their learning activities. Furthermore, Students have averagely spent 9.5 hours a day to keep in touch with their smartphone. In this case, it is supported with Csobanka (2016) who asserts that screenagers or generation z who spent their most time to surf the internet in helping their daily life by using their smartphone properly.

Students or can be categorized as screenagers were born when the technology itself has been developing, which means that they have been using since they were in early age and were able to use technology especially smartphone meaningfully. Regarding to the use of the technology as a tool of helping students' daily activities especially in learning English, English language Education students need learning materials in form of smartphone-based application media which has a combination of four English skill instead of having conventional learning activity, this statement also supported with Miangah and Nezarat (2012) who add that learning through mobile media can be useful to conduct the learning process efficiently.

The learning will be more than out of the classroom anytime instead of in the classroom and MALL also has benefit in individual learning (Klopfer, Squire, \& Jenkins. 2002). Further, students are expect a brand new learning activities that will help them to derive learning information variously such as, conducting learning activities frequently more with their smartphone, have challenging game on it which can motivate them to learn, learning grammar efficiently, have quizzes, providing with native speaker audio and video, importantly students need learning materials media-based which can integrate four skills of English and can be used everywhere and anywhere. Those found also have been supported by Laurie (2015) and Sarrab \& Elgamel (2012) assert that mobile learning helps teachers and students to lengthen the learning process out of the classroom, the instruction and flexibility of communication device offer something that will make students get new chance of knowledge instead out of traditional way in the classroom. Authentic materials and highly motivated activities are needed in order to build students' interest in learning activities and those can be integrated by using technology.

In addition, lecturers interview have collected some points for the researcher. The use of technology has been applying the learning activities in the classroom because the lecturers were aware with the character of today's students who are not fully agreed with traditional learning and it would make the students feel bored. It is also already stated by Fatimah (2017) that teaching in a conventional way or delivering material traditionally is not appropriate anymore used to face gen $\mathrm{z}$ in delivering materials, the teacher should aware in engaging students in learning activities and delivering the material more attractively. Unfortunately not all of the lecturers have implemented smartphone-based learning, only two of them had used it in the classroom while the rest still use another conventional technology such laptop and projector. It was happening because the lecturers have lack of information in selecting the proper technology. Besides, there are still rarely found an integrated materials and skills application for learning English. Another thing is lecturers were understood the implementation of technology to be used in teaching activities, it will prepare the students to face future framework, Asean Economic Community, and Industry 4.0. In essence, lecturers agree with the development of brand new supplementary media in learning English especially in learning Intensive English.

\section{Conclusion and Suggestions}

Need analysis was conducted in this study in order to identify the students' need in learning especially in learning Intensive English Course (IEC) course. Based on the interviews conducted it found that students need attractive, fun, and challenging English learning materials which more engaged with technology such as smartphone-based application to support students learning activities. In the 21 st century of learning, introducing the use of technology in improving digital literacy to the students is needed in order to make the students ready to face AEC and Industry 4.0. On the other hand, learning by the conventional way is not appropriate anymore to be conducted and developing new extraordinary media will be a breakthrough movement for the students to increase their ability in English as they need.

After conducting need analysis of the students, for further steps hopefully there is a new authentic learning materials to be developed to help students' learning in achieving their English ability especially for Intensive English Course (IEC). 


\section{References}

Bezircilioğlu, S. (2016). Mobile assisted language learning. Journal Of Educational And Instructional Studies In The World, 6(1), 9-12.

Bonces, J. R. (2012). Content and Language Integrated Learning (CLIL): Considerations in the Colombian Context. Gist Education and Learning Research Journal, 6(6), 177-189.

Csobanka, Z. E. (2016). 2 Generations Research: X , Y , Z. Acta Technologica Dubnicae, 6(2), $63-76$. https://doi.org/10.1515/atd-2016-0012

Darmuki, A., Andayani, M., Nurkamto, J., \& Saddhono, K. (2016). International Journal of Languages ' Education and Teaching Education Study Language And Literature Indonesia. International Journal of Languages' Education and Teaching, (2), 1-14. https://doi.org/10.18298/ijlet.611

Fatimah, A. S. (2017). Teaching In 21 st Century : Students- Teachers' Perceptions Of Technology Use In The Classroom. Journal of Linguistic and English Teaching, 2(2).

Hashim, H. (2018). Application of technology in the digital era education. International Journal of Research in Counseling and Education, 01(02), 1-5. https://doi.org/10.24036/002za0002

Klopfer, E.; K. Squire, and H. Jenkins. (2002). "Environmental Detectives: PDAs as a window into a virtual simulated world." In: Proceedings of IEEE International Workshop on Wireless and Mobile Technologies in Education. Vaxjo, Sweden: IEEE Computer Society, pp. 95-98

Kopáčková, H. (2016). Characteristics of digital natives generation in the context of mobile learning, (July 2015). https://doi.org/10.1109/DT.2015.7222966

Ligi, B. \& W. D. R. (2017). Mobile learning in higher education. International Journal of Research Granthaalayah, 5, 2-7.

Lorena, C., \& Sadiku, M. (2015). The Importance of Four Skills Reading, Speaking, Writing, Listening in a Lesson Hour. European Journal of Language and Literature Studies, 1(1), 29-31.

Madhumathi, G. R. \& P. (2017). Review on Use of Mobile Apps for Language Learning. International Journal of Applied Engineering Research, 12(21), 11242-11251.

Mandala Putra, M. A., \& Santosa, Made Hery, Susanti, K. R. (2018). Investigation of the Effect of Orai Smartphone-Based Application on Speaking Competency for Adult Learners. Conference ProceedingsThe Fourth International Conference On English Across Cultures, (October).

Miangah, T. M., \& Nezarat, A. (2012). Mobile-Assisted Language Learning. International Journal of Distributed and Parallel System (IJDPS), 3(1), 309-319.

Phuapan, Piatip, Viriyavejakul, chantana, \& Pimdee, P. (2015). Elements of Digital Literacy Skill. International Conference on Developing Real-Life Learning Experience: Lifelong Learning Skills in The 21st Century $E L$, (June). Retrieved from www.inded.kmitl.ac.th/DRLE2015 Faculty

Sarrab, M., \& Elgamel, L. (2012). M Obile L Earning ( M-L Earning ) and, (July), 31-38.

Sato, T., Murase, F., \& Burden, T. (n.d.). Is mobile-assisted language learning really useful ? An examination of recall automatization and learner autonomy, (2015), 495-501.

Sugiyono. (2010). Metode Penelitian Kuantitatif Kualitatif dan R\&D. Bandung: Alfabeta.

Ulum, Ö. G. (2016). A Needs Analysis Study For Preparatory Class Elt Students. European Journal of English Language Teaching, 1(January 2015). https://doi.org/10.5281/zenodo.51774

Zhang, H., \& Burston, J. (2011). Reexamining The Effectiveness of Vocabulary Learning Via Mobile. Tojet: The Turkish Online Journal of Educational Technology, 10(3), 203-214. 